\title{
Study of clay used in the production of red ceramic pottery on semi-arid Cearense, Brazil
}

\author{
Leonardo Alves Pinto ${ }^{1}$, Thalia Delmondes de Souza ${ }^{1}$, \\ Daniel Bernardes Silva ${ }^{1}$, Lizienny Pinheiro Peixoto ${ }^{1}$, \\ Maria Isabel Brasileiro Rodrigues ${ }^{1}$
}

\author{
${ }^{1}$ Materials Engineering Department, Federal University of Cariri, Science and Technology Center, University City, S / N, \\ CEP: 63048-080, Juazeiro do Norte, Ceará, Brazil. \\ e-mail: leonardo18.pinto@gmail.com, thaliadelmondes29@gmail.com,dbsilva299@gmail.com, \\ lilyengmateriais@gmail.com, isabel.rodrigues@ufca.edu.br.
}

\begin{abstract}
Red ceramics are part of one of the sectors of ceramic materials that make up the formation of the civil construction complex. In Cariri region and in the rest of Brazil, this segment uses clay as the main source of raw material, which favors the appearance of micro, small and medium enterprises that produce most of the products manufactured by the red ceramic sector. The objective of this work was the mineralogical and technological characterization of a clay sample from one of the potteries in Cariri region, intended for the manufacture of products to be used in civil construction such as tiles and bricks. For that, the techniques of X-ray fluorescence and X-ray diffraction were used, in addition to determining the physical-mechanical properties of the specimens by 4 ton-force uniaxial pressing followed by firing at 800,900 and $1000^{\circ} \mathrm{C}$. The results showed that the sample is composed of quartz, kaolinite, smectite and muscovite and that it has granulometry mostly in fine fractions; after firing the clay shows reddish color and the Atterberg limits are within the range indicated for use on red ceramics. The clay under study has technological properties suitable for manufacture and the specimens burned at $800^{\circ} \mathrm{C}$ do not meet the values indicated by the literature. The studied clay proved to be suitable for application in tiles and perforated bricks.
\end{abstract}

Keywords: Red ceramics; Clay; Cariri region.

\section{INTRODUCTION}

The Brazilian ceramics sector is of great importance for the country, both in terms of the generation of foreign exchange and the generation of jobs, with the industrial segment of red ceramics being the most prominent. With approximately 6903 ceramic companies and potteries spread across the country, it is estimated an annual turnover of around $\mathrm{R} \$ 18$ billion and a share of approximately 293 thousand direct jobs and 900 thousand indirect jobs $[1,2]$.

Red ceramics are characterized within the ceramic sector, due to the red color of their products mainly intended for civil construction such as roof tiles, bricks, tiles, structural and sealing blocks, among others [3]. This segment represents $4.8 \%$ of the construction industry and $90 \%$ of all masonry and roofing constructed in Brazil [1].

Despite this importance, the industrial field of red ceramics in the country is still considered to be quite artisanal, as it mainly has micro, small and medium-sized enterprises. Most of them are characterized by simple and familiar organization that work with outdated production processes, outdated methods and systems that spend a lot of material and energy, in addition, these projects are subject to a series of economic, environmental and quality problems of manufactured products that, in general, have low added value making it impossible to grow and modernize these $[4,5]$.

The constitution of this segment by small enterprises is linked to the abundance of the main raw material, clays, its low cost, the ease of access that, in general, is located in the vicinity of the ceramics industries and its relatively simple processing. In that last, the red ceramic manufacturing process generally takes place by using a ceramic mass resulting from the mixture of a clay of high and another of low plasticity which are known in non-technical terms as "lean" and "fat" clays, submitted to homogenization and molding by manual 
processes, extrusion and pressing, followed by drying and firing [6].

The clays used in the process have, in general, very fine granulometry, different degrees of plasticity when in the presence of a certain percentage of water, good workability, resistance to green enough for handling, dry and after firing; carried out at temperatures ranging from 800 to $1250^{\circ} \mathrm{C}$, depending on the nature of the clays. The characteristics of this raw material depend on the geological formation and the location of extraction $[7,8]$.

In a study, RACANELLI, et al. [9] carried out physical, chemical and mechanical characterizations in two clays in the Northeast region of the state of Pará, Brazil. Specimens were prepared by uniaxial pressing with a pressure of $20 \mathrm{Mpa}$ and burned at temperatures of 850,950 and $1050^{\circ} \mathrm{C}$. As a result, the clays found were composed of kaolinite, which can present good plasticity, with high levels of silica and low levels of alumina. The physical-mechanical results indicated that the clays had characteristics favorable to the production of red ceramics, specifically sealing blocks.

Based on the characterization of clay deposits in the southern region of Amapá, carried out by SILVA, et al. [10] and SILVA, et al. [11], they were found to have kaolinite, mica and quartz composition. In addition, for both, the physical-mechanical properties obtained in specimens by uniaxial pressing at $20 \mathrm{Mpa}$ as the water absorption content, tend to decrease with increasing firing temperature, while the rupture module grows with increasing temperature. Clays have characteristics suitable for applications in the red ceramic industry and others for applications in dense refractories.

Another study on the characterization of clays in Brazil was carried out by RAMOS, et al. [12] in Parelhas in Rio Grande do Norte. The authors carried out the physical, chemical and mineralogical characterization of samples from new deposits in this region. They observed that the clays were composed of kaolinite and smectite clay minerals containing quartz and feldspar. According to Atterberg's limits, the samples were classified as highly plastic. Finally, clays have the potential to be used as a raw material in the red ceramic industry.

The characteristics and technological properties of clays used in the red ceramic industry in São Domingos do Sul in the northern region of Rio Grande do Sul, were determined by PÉREZ, et al. [5] with the elaboration of specimens also by uniaxial pressing at $20 \mathrm{Mpa}$ and in two firing temperatures, 800 and $900^{\circ} \mathrm{C}$. The authors observed that the clays are basically formed by kaolinite, quartz, oxides and hydroxides of Fe. The ceramic masses are highly plastic and most of them have characteristics suitable for extrusion molding.

BRITO, et al. [13] carried out physical, chemical, mineralogical and thermal characterizations on four clays from deposits in the municipality of Cubati in Paraíba, Brazil. For the study, specimens were made by uniaxial pressing at $19 \mathrm{Mpa}$ and burned at four temperatures ranging from 750 to $1150^{\circ} \mathrm{C}$. The main oxides present in the clays were $\mathrm{SiO}_{2}, \mathrm{Al}_{2} \mathrm{O}_{3}$ and $\mathrm{Fe}_{2} \mathrm{O}_{3}$ and these were made up of smectite, quartz and kaolinite. According to the physical-mechanical properties of the four clays, only one presented excellent characteristic for the production of red ceramics.

And this way leads to industrial processes the need to identify the type of clay and its mineralogical and technological characteristics, since the properties of the final product are directly interconnected with the initial particularities of the raw material. In addition, the knowledge of these makes it possible to establish suitable formulations, as well as to improve the processing conditions in order to reduce production costs, ensure the required quality of the products and increase their added value; and these are the big impasses of small ceramic enterprises $[7,8]$.

In state of Ceará, red ceramics is a traditional branch with a structure of micro, small and mediumsized enterprises [14]. According to data collected by Revista da FIEC [15], in 2013, there were a total volume of 412 industries in activity in that state, distributed in 93 municipalities. In Cariri region, located in the south of Ceará (Figure 1), according to Souza [16] and Alves [17] the number of industries comprising the ceramics pole in this region is about 20 companies with a family profile distributed in six municipalities, being Crato, which stands out for concentrating the largest number of projects. These produce a large amount of structural materials, mainly tiles and blocks intended for civil construction.

Despite the importance that the ceramics pole presents for the Cariri region and knowing that, the knowledge of the mineralogical and technological characteristics of the used clays can provide improvements in the development of ceramics activities in the region, little research has been carried out on the properties of the clays used and these are suitable properties required for the manufacture of red ceramic products. Therefore, it needs more studies with this approach in order to have an understanding of the characteristics of the clays used and if they are suitable for the manufacture of the materials, which are intended.

Within this context and in order to contribute to the development of ceramics activities and enterprises 
that have deficiencies regarding the adequacy of formulations and processing conditions of the ceramic mass used in the manufacture of red ceramics. The present work aims to present a study, through the mineralogical and technological characterization of one of the most used clays in the manufacture of structural ceramic products, which comes from one of the main potteries in the Cariri region. It also aims to analyze the influence of heat treatment on the clay under study, making it possible to relate the temperature and the type of product to be manufactured with the required final quality.

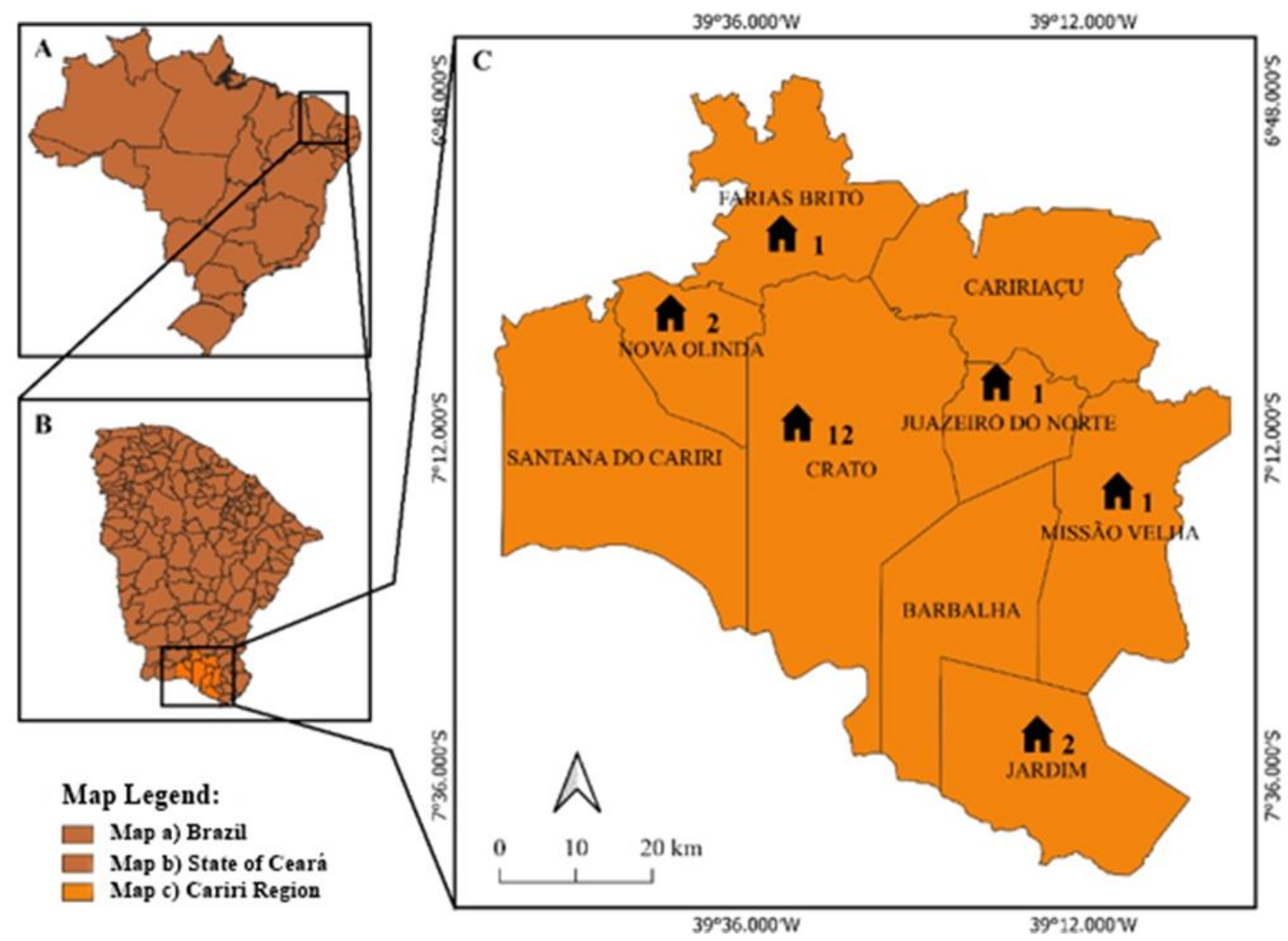

Figure 1: Location map of the Cariri region and the distribution of the number of companies by municipalities.

\section{MATERIALS AND METHODS}

The granulometric distribution was determined according to NBR 7181/16 [18]. At first, 100g of clay, deflocculant and water were separated and then the sifting technique was used up to the size of $200 \mathrm{mesh}$. Below this diameter, the sedimentation technique was used. The use of deflocculants for this process is relevant so that the particles remain deflocculated and do not agglomerate.

The plasticity characteristics were determined using the Attenberg limits. The liquidity limit (LL) was performed using the Casagrande test following NBR 6459/16 [19] and the limit and plasticity index following NBR 7180/16 [20]. The chemical composition was determined by X-ray fluorescence with equipment from Shimazdu EDX 720, and by X-ray diffraction from Shimadzu, XRD 6000 with CuK $\alpha$ radiation (40kV, $30 \mathrm{~mA}, 0.02^{\circ}$ step) and $2 \theta$ scan from 5 to $50^{\circ}$. (Cristallography Open Database) using the Match! 3 software.

To determine the technological properties, 30 proof bodies were molded through the uniaxial pressing process, using a rectangular steel matrix with internal dimensions of $80 \times 25 \mathrm{~mm}$. For this, a moisture content of $7.0 \%$ of the total weight of the clay was added and left for 24 hours for homogenization. Shortly after filling the mold with an amount of mass sufficient to obtain a body of approximately $25 \mathrm{~g}$, compaction was carried out by applying a pre-press under a load of 2 ton-force, so that there is air release between the particles and later, a press of 4 ton-force, being finally removed. The compression load values were determined according to observations in the literature $[9,10]$.

After the shaping step, the specimens were dried at $100^{\circ} \mathrm{C}$ for 24 hours and subsequently burned in an oven at temperatures of 800,900 and $1000^{\circ} \mathrm{C}$, at a heating rate of $10^{\circ} \mathrm{C} \cdot \mathrm{min}^{-1}$ and kept on the landing for 2hour. The firing temperature values were determined according to the usual in ceramic industries and the literature values $[9,10]$. The cooling occurred by natural convection, turning the oven off. After this process, technological tests were carried out to determine the physical-mechanical properties of the linear burning shrinkage, apparent density, water absorption and the flexural strength tension. 


\section{RESULTS AND DISCUSSIONS}

According to NBR 6502/95 [21] clay fraction is considered, particles with dimensions smaller than 0.002 $\mathrm{mm}$, while silt comprises diameters between 0.002 and $0.06 \mathrm{~mm}$ and, dimensions greater than 0.06 and smaller or equal at $2.0 \mathrm{~mm}$ are called the sand fraction. The first presents good cohesion and plasticity when in contact with water, a different result occurs with the sand fraction, which is non-cohesive and non-plastic. Then, with these considerations, it can be seen in Figure 2 that the sample analyzed presented approximately the following distribution: $19.6 \%$ clay, $46.6 \%$ silt and $33.8 \%$ sand. These granulometric results show that the sample has mostly fine fractions, which can give the ceramic mass a high plasticity and contribute to a greater packaging of the particles during pressing and in sintering during firing; since the particles have a greater reactivity with each other, due to having a higher surface area. Such characteristics can be important for more specific productions that require greater plasticity, bringing advantages for conformation by extrusion or molding.

There's no doubt that the granulometry of the ceramic mass can significantly alter the plasticity, workability, density, processing, conformation, drying of the material and mechanical resistance. The levels of finer or coarser fractions can modify the proportions to obtain the best mixture of particle sizes that the final product requires. Difficulties in processing in many cases can be attributed to uneven distribution of granulometry, so formulations that manage to bring the final composition to the effectiveness of associating the properties of the clay, silt and sand fractions are relevant $[22,23]$.

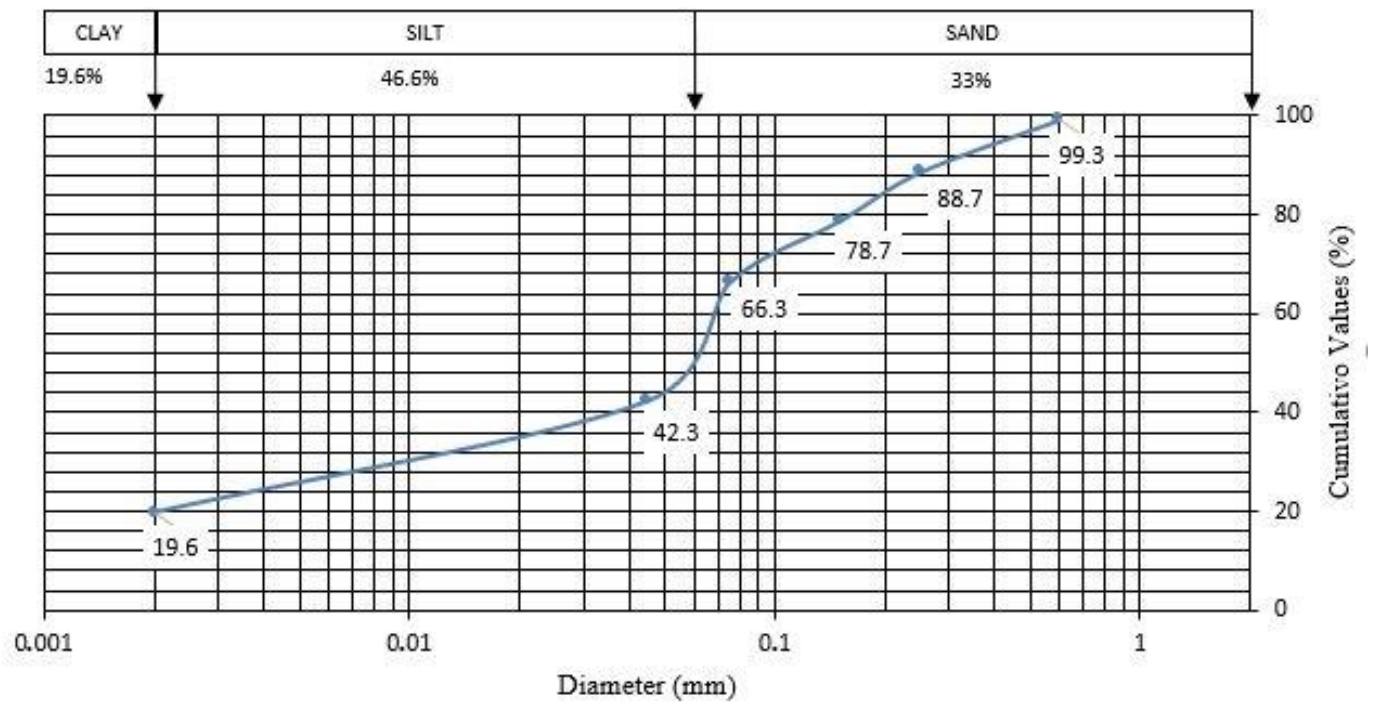

Figure 2: Granulometric distribution of clay.

Table 1 shows the chemical composition of the sample under study. It's possible to observe a typical result of clay used in the production of red ceramics, where there're a predominance of silicon dioxide $\left(\mathrm{SiO}_{2}\right)$, aluminum oxide $\left(\mathrm{Al}_{2} \mathrm{O}_{3}\right)$ and iron oxide $\left(\mathrm{Fe}_{2} \mathrm{O}_{3}\right)$ [5, 24, 25]. It's observed that the highest content in weight in the sample is $\mathrm{SiO}_{2}$ with $62.308 \%$, since it can be present both in the structure of clay minerals, as well as in the form of free quartz. $\mathrm{SiO}_{2}$ present in the structure of clay minerals and combined with accessory minerals such as $\mathrm{Al}_{2} \mathrm{O}_{3}, \mathrm{~K}_{2} \mathrm{O}, \mathrm{MgO}$ and $\mathrm{CaO}$ can form, during burning, the glass phase [26]. The second that has the highest content is $\mathrm{Al}_{2} \mathrm{O}_{3}$ with $24.826 \%$, probably being associated with kaolinite [27]. $\mathrm{Fe}_{2} \mathrm{O}_{3}$ presents a percentage of $5.937 \%$, which indicates that after burning the product will present a reddish color due mainly to the oxidation of the iron compound [28]. The $\mathrm{K}_{2} \mathrm{O}, \mathrm{MgO}$ and $\mathrm{CaO}$ present in the sample are the main fluxing oxides, they help in the formation of the glass phase (vitrification) during firing and reduce the sintering temperature promoting more easily the densification of the ceramic body [29]. sample also presents fractions of $\mathrm{TiO}_{2}, \mathrm{SO}_{3}, \mathrm{MnO}, \mathrm{ZrO}_{2}$ and $\mathrm{Ag}_{2} \mathrm{O}$. 
Table 1: Chemical composition of clay.

\begin{tabular}{c|c}
\hline COMPOSITION & PERCENTAGE (\% BY WEIGHT) \\
\hline $\mathrm{SiO}_{2}$ & 62.308 \\
\hline $\mathrm{Al}_{2} \mathrm{O}_{3}$ & 24.826 \\
\hline $\mathrm{Fe}_{2} \mathrm{O}_{3}$ & 5.937 \\
\hline $\mathrm{K}_{2} \mathrm{O}$ & 2.699 \\
\hline $\mathrm{MgO}$ & 2.398 \\
\hline $\mathrm{TiO}_{2}$ & 1.045 \\
\hline $\mathrm{CaO}$ & 0.455 \\
\hline $\mathrm{SO}_{3}$ & 0.153 \\
\hline $\mathrm{MnO}$ & 0.074 \\
\hline $\mathrm{ZrO}_{2}$ & 0.044 \\
\hline $\mathrm{Ag}_{2} \mathrm{O}$ & 0.024 \\
\hline
\end{tabular}

In the clay in natura diffractogram, Figure 3, diffraction peaks were found referring to the crystalline phases of quartz $\left(\mathrm{SiO}_{2}\right)$, kaolinite, smectite in specific of the montmorillonite type and muscovite mica. $\mathrm{Re}$ lating the diffraction patterns and the chemical composition (Table 1), it was possible to notice that the kaolinite present is in the badly crystallized form, because according to MACEDO, et al. [27], the diffraction peaks present with low intensity and because there is a high content of aluminum oxide present in the sample, it is not in the form of phases which are sources of this oxide in high quantity such as gibsite or bohemite. Smectite and muscovite are the main sources of the $\mathrm{K}_{2} \mathrm{O}, \mathrm{MgO}$ and $\mathrm{CaO}$ oxides present. The kaolinite and montmorillonite clay minerals observed, favor the development of the plasticity of the ceramic masses when moistened, since an interparticle film of water is formed facilitating the sliding between them, an effect known as hydroplasticity; and, in addition, its lamella-like structure and fine granulometry gives a large surface area [24]. The presence of high levels of clay minerals would provide high values of plasticity to the mass, which would be inappropriate or would compromise some manufacturing processes. With this, the quartz present, acts as a reducer of the plasticity in the mass, balancing these values, being one of the possible reasons for having masses with plasticity limits suitable for red ceramic [27]. In addition, in the firing stage, it facilitates the drying process and minimizes the retraction of the ceramic piece [30].

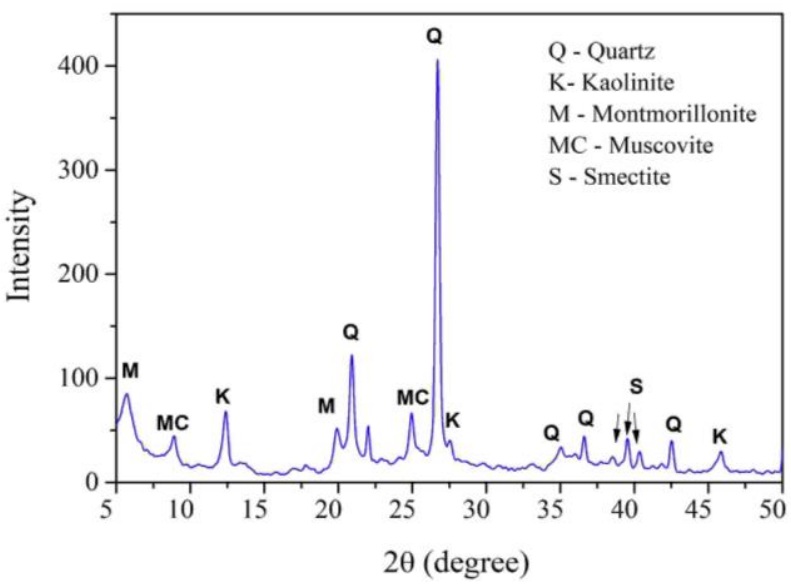

Figure 3: X-ray diffractogram of the clay in natura under study and its main crystalline phases.

The results obtained from Table 2 were determined using the Atterberg and plasticity indexes. Based on data in the bibliography $[24,27]$ it is noted that the values achieved are within the ranges of 30 to $60 \%$ for LL, 15 to $30 \%$ for LP and 10 to $30 \%$ for IP, observed for ceramics red. Through the Jenkins classification [31, $32]$, in which the soils can be categorized into weakly plastics $1<\mathrm{IP}<7$, moderately plastics $7<$ IP $<15$ and highly plastics IP> 15, it is observed that the sample fits this last category, for having an IP content of $18.9 \%$. 
This result can probably be attributed to the presence of kaolinitic and montmorillonite clay minerals [24].

According to SANTOS, et al. [33] the plasticity index values and the plasticity limit can be categorized clays into characteristic areas of acceptable, optimal or excessively plastic extrusions. The acceptable one presents an IP between 10 and 34\% and an LP remaining between 18 and 31\%, however, for an optimal extrusion the clay must present a plasticity index between 15 and $25 \%$ whereas the plasticity limit must be between 18 and $25 \%$. Based on these considerations, it can be noted that the ceramic sample is not suitable for classifying clays in the extrusion zone. Because of this, many ceramic enterprises mix with different types of clay to obtain the plasticity necessary to process the masses by extrusion.

Table 2: Atterberg limits of the sample.

\begin{tabular}{c|l|l|l}
\hline SAMPLE & LL (\%) & LP (\%) & IP (\%) \\
\hline Clay & 35.7 & 16.8 & 18.9 \\
\hline
\end{tabular}

Figure 4 shows the color of the specimens after burning at temperatures of 800,900 and $1000^{\circ} \mathrm{C}$. It is observed that the samples have an orange-red hue, resulting from the content of iron oxide present in the clay, which is $5.937 \%$, as shown in Table 1 . Therefore, it is one of the important characteristics for the production of red ceramics. It is also noted that there was no color change as significant with an increase in temperature; however, the little shade variation that occurred may be associated with the release of $\mathrm{Fe}^{2+}$ at temperatures close to $1000^{\circ} \mathrm{C}$, as observed by ROVERI, et al. [34].

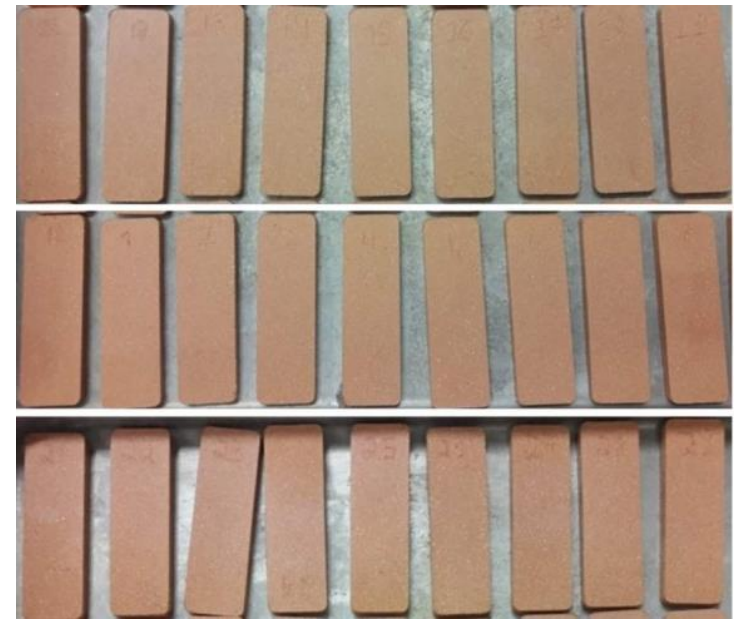

$800^{\circ} \mathrm{C}$

$900^{\circ} \mathrm{C}$

$1000^{\circ} \mathrm{C}$

Figure 4: Colors of the specimens after firing at 800,900 and $1000^{\circ} \mathrm{C}$.

During the first drying stage of the specimens of the sample, there was a linear retraction of $0.42 \%$, this is the result of the evaporation of the processing water which, when it is eliminated and when the spaces left by it appear, there is an approximation of the particles as a result of the forces of electrostatic attraction, causing drying and contraction in the dimensions of the material $[35,36]$. A strict control of the shrinkage on drying is beneficial for the later stages of the production of ceramic pieces, since there will be a closer approximation of the particles, reducing porosity and facilitating the sintering process.

The results of the technological tests of the clay after firing at 800,900 and $1000^{\circ} \mathrm{C}$, are illustrated in Figures 5, 6 and 7. Figure 5 shows the values of the linear shrinkage of the firing and the apparent density. It was noted that these two properties increase as the firing temperature rises. These results for both can be attributed to a higher liquid phase content at higher temperatures [37], caused by the melting of the fluxing oxides present in the chemical composition of the sample as shown in Table 1, which provide even more the approximation of the solid particles and the filling of the empty spaces between them, generating physical changes such as volume contraction [13]. Therefore, the retraction value was below 1\%, which is important, as mentioned by ZACCARONA, et al. [35], AMORIM [38], VIEIRA and SILVA [39], these should not exceed $6 \%$, since they can cause problems of deformation in the ceramic body, facilitating the nucleation of cracks in the final product. 


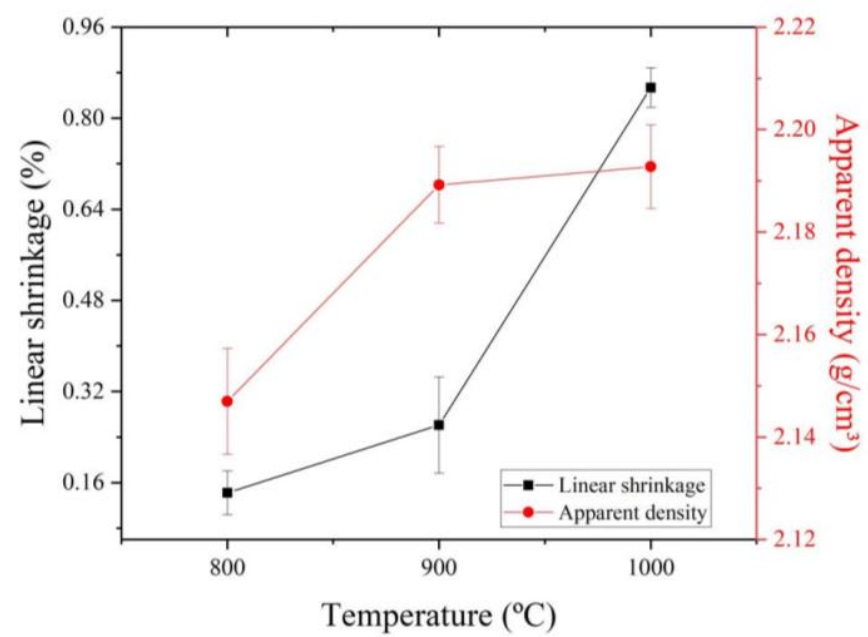

Figure 5: Linear shrinkage and clay apparent density.

Regarding the loss to fire (Figure 6), it appears that the samples showed a loss of $8.75 \%, 8.76 \%$ and $8.89 \%$ for temperatures of 800,900 and $1000^{\circ} \mathrm{C}$, respectively. It is clear that the higher the burning temperature, the higher the loss to fire. Despite this increase, the variation in this parameter is not so significant. The losses analyzed are probably related to water evaporation (adsorbed or combined), burning of organic matter and / or loss due to dehydroxylation of the clay minerals present in the sample [24, 25, 37]. Loss to fire is the main reason for the appearance of porosity in a ceramic body and samples with high loss have an increase in porosity. However, in relation to the burning temperature increase, the opposite result occurs even with the increase in loss to fire, as shown in Figure 6. It is observed that there is a decrease in the apparent porosity, going from 25.05 to $23.02 \%$ with the increase of the burning temperature from 800 to $1000^{\circ} \mathrm{C}$, a result that can refer to the increase of the vitreous phase due to the fluxing oxides function that fills the voids left by the loss of material. This result corroborates the increase in apparent density, as they are intrinsically related [13, $16,24,27]$

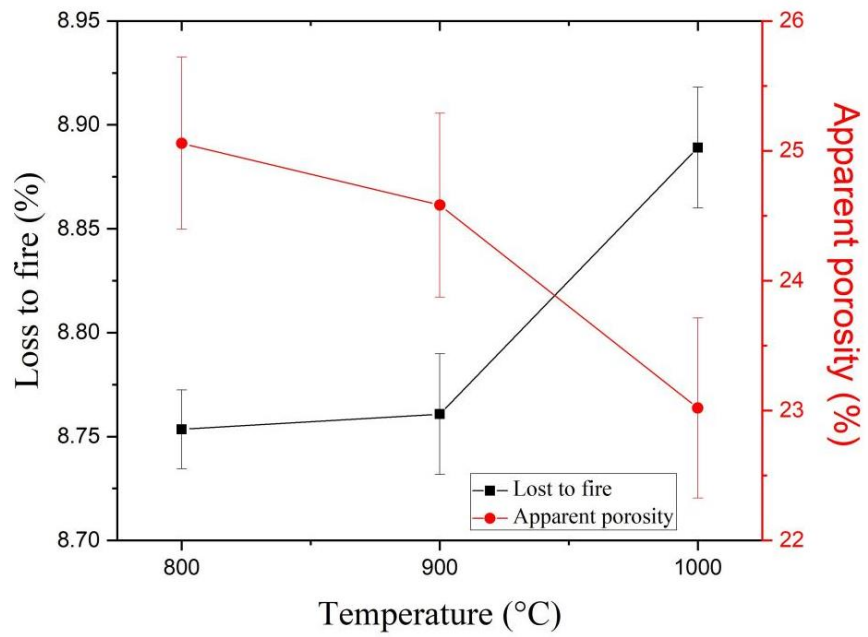

Figure 6: Loss to fire and apparent porosity data at 800,900 and $1000^{\circ} \mathrm{C}$ firing temperatures.

Figure 7 shows the water absorption and flexural strength at the aforementioned firing temperatures. The values obtained for the water absorption content in the sample showed a reduction with the increase in temperature and an opposite result occurred with the flexural strength tension. These two results would probably be related to the reduction in porosity due to the increase in apparent density with the increase in temperature. For the temperature of $800^{\circ} \mathrm{C}$, a higher water absorption index and lower resistance to flexion are observed, this occurs because the sintering reactions are still in the initial stage and therefore the phase transformations that occur at that first temperature, can result in an increased porosity in the ceramic body, as seen in the apparent porosity results, Figure 6 . For higher temperatures, 900 and $1000^{\circ} \mathrm{C}$, the phase transformations are in more advanced stages, favoring greater formation of the vitreous phase, which provides for a 
reduction of the pores allowing greater packaging in the internal structure of the ceramic piece. Consequently, it hinders the absorption of water and confers a lower number of weakening points which prevent the applied stress from being completely absorbed and evenly distributed in the ceramic body structure [40, 41], thus reflecting higher values of flexural strength.

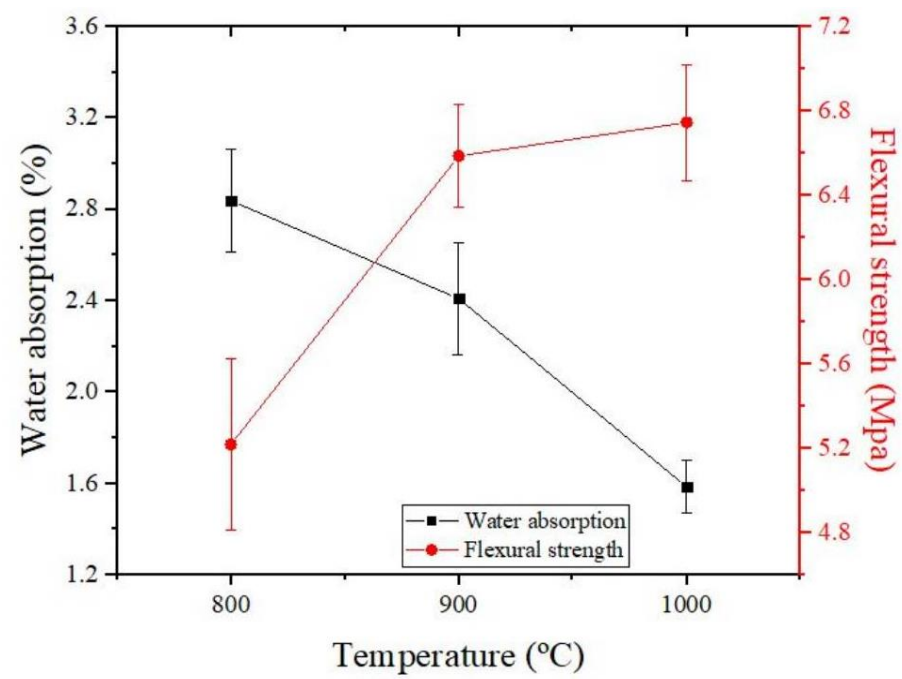

Figure 7: Water absorption and clay flexural strength.

Comparing the water absorption values and the flexural strength tension of the clay, obtained at different firing temperatures, with the limits indicated for masonry bricks, perforated bricks and tiles as reported in the literature and standards [24, 42, 43], Figure 8, it is possible to infer the type of product that can be manufactured by the sample and the firing temperature that will meet the necessary requirements for the product. As a result, it is observed that at temperatures of 900 and $1000^{\circ} \mathrm{C}$ the values are within those recommended for perforated tiles and bricks. However, at $800^{\circ} \mathrm{C}$ the result is not ideal for the production of any of the analyzed products, due to the values being outside the minimum and maximum flexural strength and water absorption tension suggested by the literature.

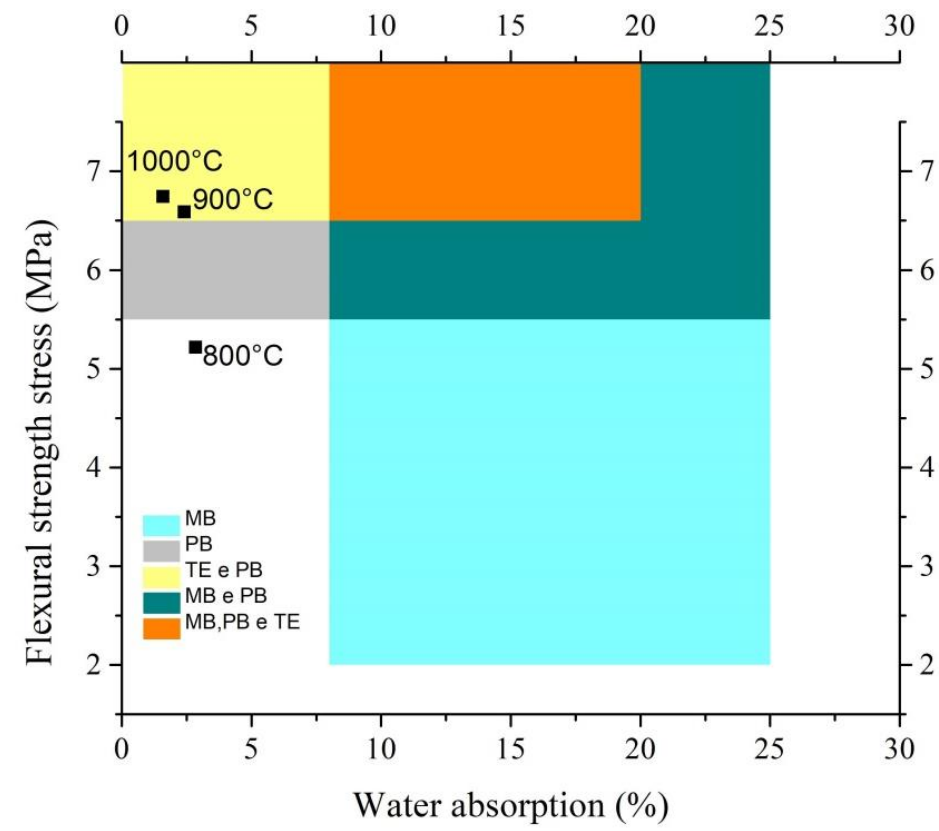

Figure 8: Indicated water absorption regions and flexural rupture module for masonry bricks (MB), perforated bricks (PB) and tiles (TE) according to [24, 42, 43] and the respective values obtained from the clay at temperatures firing temperatures of 800,900 and $1000^{\circ} \mathrm{C}$ according to Figure 7 . 


\section{CONCLUSION}

The sample under study consists basically of quartz, kaolinite, smectite and muscovite; after firing shows reddish color; it has granulometry mostly in fine fractions: silt and clay; and the Atterberg limits are within the range indicated for use on red ceramics. The properties of linear shrinkage, water absorption, flexural stress and apparent density obtained in the laboratory showed good results as the firing temperature increases. From the characterization of the sample, it was found that it is suitable for applications in perforated bricks and tiles at firing temperatures at 900 and $1000^{\circ} \mathrm{C}$. However, at $800^{\circ} \mathrm{C}$ the values obtained do not fit in any of the analyzed products.

With this, the present work makes it possible to predict the behavior of the sample during the processing of the ceramic pieces, as well as their performance, making it possible to point out and adapt the conditions necessary to maximize production, promoting the development of the ceramic industries in the region. In addition, the work contributes to fill the gap in the literature of studies related to clays in Cariri region.

\section{BIBLIOGRAPHY}

[1] ANICER, ASSOCIAÇÃO NACIONAL DA INDÚSTRIA CERÂMICA, https://www.anicer.com.br. Accessed in April 2019.

[2] PRADO, U.S., BRESSIANI, J.C., "Panorama da indústria cerâmica brasileira na última década", Cerâmica Industrial, v. 18, n. 1, pp. 7-11, 2013.

[3] MOTTA, J.F.M., ZANARDO, A., CABRAL JUNIOR, M., "As matérias-primas cerâmicas. Parte I: o perfil das principais indústrias cerâmicas e seus produtos", Cerâmica Industrial, v. 6, n. 20, pp. 28-39, 2001.

[4] BRAGA, W.A., SANTOS, M.W.L.C., SALES, J.C., "Qualidade na Indústria de Cerâmica Vermelha: Medidas e Alternativas para o Controle Dimensional", Cerâmica Industrial, v. 20, n.5/6, pp. 40-43, 2016.

[5] PÉREZ, C.A.S., PADUANI, C., ARDISSON, J.D., et al., "Caracterização de massas cerâmicas utilizadas na indústria de cerâmica vermelha em São Domingos do Sul-RS", Cerâmica Industrial, v. 15, n. 1, pp. 38-43, 2010.

[6] TEIXEIRA, S.R., "Caracterização de argilas usadas para produção de cerâmica vermelha e estudo das alterações nas suas propriedades pela adição de resíduos sólidos", Tese de D.Sc., UNESP, Presidente Prudente, SP, Brasil, 2006.

[7] CABRAL JUNIOR, M., TANNO, L.C., SINTONI, A., et al., "A indústria de cerâmica vermelha e o suprimento mineral no brasil: desafios para o aprimoramento da competitividade", Cerâmica Industrial, v. 17, n. 1, pp. 36-42, 2012.

[8] MENEZES, R.R., SOUTO, P.M., SANTANA, L.N.L., et al., "Argilas bentoníticas de Cubati, Paraíba, Brasil: Caracterização física-mineralógica". Cerâmica, v. 55, pp. 163-169, 2009.

[9] RACANELLI, L.A., CÂNDIDO, V.S., SOUZA, J.A.S., et al., "Caracterização e Estudo das Propriedades Físicas, Químicas e Mecânicas das Argilas Cauliníticas da Região Nordeste do Estado do Pará", Revista Matéria, v. 25, n. 1, 2020.

[10] SILVA, A.L., LUNA, C.B.B., CHAVES, A.C., et al., "Caracterização tecnológica de novos depósitos de argilas da região sul do Amapá visando aplicações na indústria Cerâmica", Revista Matéria, Rio de Janeiro, v. 22, n. 1, 2017.

[11] SILVA, A.L., LUNA, C.B.B., CHAVES, A.C., et al., "Avaliação de novos depósitos de argilas provenientes da região sul do Amapá visando aplicação na indústria cerâmica". Cerâmica, v. 64, n. 369, pp. 69-78, 2018.

[12] RAMOS, S.O., DANTAS, G.C.B., LIRA, H.L., et al., "Caracterização de argilas de novos jazimentos situados em Parelhas/RN, Brasil, visando aplicação na indústria cerâmica". Revista Matéria, v.24, n.2, 2019.

[13] BRITO, I. P., ALMEIDA, E.P., NEVES, G.A., et al., "Avaliação de novos depósitos de argilas do Estado da Paraíba visando sua aplicação como matérias-primas cerâmicas". Cerâmica, v. 61, n. 360, pp. 391- 398, 2015.

[14] LIMA, R.H.C., "Estudo de formulação de massas através do controle da mistura: argilas aluvionares do pólo cerâmico de Russas", Tese de D.Sc., IGCE/UNESP, Rio Claro, SP, Brasil, 2009.

[15] REVISTA DA FIEC - Federação das Indústrias do Estado do Ceará, Ano 7, n76, Fortaleza, 2013.

[16] SOUZA, J.P., "Caracterização tecnológica de argilas utilizadas na fabricação de cerâmicas vermelhas no município do Crato- Ceará”, Dissertação de M.Sc., UFC, Fortaleza, CE, Brasil, 2017. 
[17] ALVES, C.L.B., "Responsabilidade socioambiental: uma avaliação do setor de cerâmica na Região Metropolitana do Cariri - Ceará”, Tese de D.Sc., DDMA/UFC, Fortaleza, CE, Brasil, 2017.

[18] ASSOCIAÇÃO BRASILEIRA DE NORMAS TÉCNICAS. NBR 7181- Solo - Análise granulométrica. Rio de Janeiro, 2016.

[19] ASSOCIAÇÃO BRASILEIRA DE NORMAS TÉCNICAS. NBR 6459: Solo- Determinação do Limite de liquidez. Rio de Janeiro, 2016.

[20] ASSOCIAÇÃO BRASILEIRA DE NORMAS TÉCNICAS. NBR 7180: Solo- Determinação do Limite de Plasticidade. Rio de Janeiro, 2016.

[21] ASSOCIAÇÃO BRASILEIRA DE NORMAS TÉCNICAS. NBR 6502: Rochas e solos. Rio de Janeiro, 1995.

[22] MORENO, M.M.T., BARTOLOMEU, D., LIMA, R.H.C. “Análise do comportamento de queima de argilas e formulações para revestimento cerâmico”. Cerâmica, v. 55, n. 335, pp. 286-295, 2009.

[23] SANTOS, R.C., SILVA, T.R., NEVES, G.A., et al., "Interação entre características de argilas e parâmetros de processamento sobre propriedades tecnológicas de corpos cerâmicos". Cerâmica, v. 63, n. 367, pp. 361-368, 2017.

[24] SANTOS, P.S., Ciência e tecnologia das argilas, 2 ed., São Paulo - BR, Editora Edgard Blucher LTDA, 1989.

[25] SILVA, A.L., CHAVES, A.C., NEVES, G.D.A. "Technological characterization of new clay deposits in the south region of Amapá aiming applications in the ceramic industry". Revista Matéria, v. 22, n. 1, 2017.

[26] SOARES, R.A.L., NASCIMENTO, R.M., PASKOCIMAS, C.A., et al., "Avaliação da adição de dolomita em massa de cerâmica de revestimento de queima vermelha”. Cerâmica, v. 60, n. 356, pp. 516-523, 2014.

[27] MACEDO, R.S., MENEZES, R.R., NEVES, G.A., et al., "Estudo de argilas usadas em cerâmica vermelha”, Cerâmica, v. 54, n. 332, pp. 411-417, 2008.

[28] MACÊDO, R.S., "Estudo comparativo entre massas cerâmicas industriais e aditivadas para uso em blocos cerâmicos”, Tese de D.Sc., UFCG. Campina Grande, PB, 2005.

[29] VIEIRA, C.M.F., SOARES, T.M., SÁNCHEZ, R., et al., "Incorporation of granite waste in red ceramics". Materials Science and Engineering: A, v. 373, n. 1-2, pp. 115-121, 2004.

[30] SOARES, R.A.L., CASTRO, R.J.S., NASCIMENTO, R.M. "Estudo da potencialidade da aplicação de uma argila contaminada com calcário na produção de placas cerâmicas". Cerâmica, v. 58, n. 348, pp. 475480, 2012.

[31] CAMPOS, L.F.A., MACEDO, R.S., KIVOHARA, P.K., et al., "Características de plasticidade de argilas para uso em cerâmica vermelha ou estrutural”. Cerâmica, v. 45, n. 295, pp. 140-145, 1999.

[32] CAPUTO, H. P., Mecânica dos solos e suas aplicações, 6 ed., Rio de Janeiro, Livros Técnicos e Científicos, pp. 219, 1987.

[33] SANTOS, C.V.P., SILVA, A.R., FILHOS, M.A.S.G., et al., "Índice de Plasticidade e Análise Racional de Argilas de Marabá (PA) para Avaliação das Zonas de Extrusão”. Cerâmica Industrial, v. 17, n.2, pp. 2527, 2012.

[34] ROVERI, C.D., ZANARDO, A., MORENO, M.M.T., "Variação da cor e propriedades cerâmicas com o aumento da temperatura de queima de uma argila proveniente da formação Corumbataí, região de Piracicaba (SP)", Cerâmica, v. 53, n. 328, pp. 436, 2007.

[35] ZACCARONA, A., BERNARDIN, A.M., ROSSO, F., et al., "Utilização de Vidro de Garrafas para Redução da Absorção de Água em Produtos de Cerâmica Vermelha". Cerâmica Industrial, v. 20, n.5/6, pp. 35$39,2016$.

[36] WEIZENMANN, M., BRUXEL, F.R., SANTANA, E.R.R., et al., "Avaliação da incorporação de resíduo de gemas na massa cerâmica vermelha - um estudo de caso”. Cerâmica, v. 59, n. 351, pp. 442-447, 2013. [37] MELCHIADES, F.G., DEL ROVERI, C., SOTÉRIO, J., et al., "Controle dimensional e do formato de revestimentos cerâmicos; parte 1: dimensões”, Cerâmica Industrial, v. 6, n. 5, pp. 27-33, 2001.

[38] AMORIM, F.R., “Co-processamento de dregs em argila para produção de cerâmica vermelha”, Tese de D.Sc., UFMG, Belo Horizonte, MG, Brasil, 2007. 
[39] VIEIRA, G., SILVA, D.F., "Estudo da adição de lodo gerado pela indústria metal mecânica na fabricação de tijolos de cerâmica vermelha", E-Tech: Tecnologias para Competitividade Industrial, pp. 69-91, 2012. [40] PINHEIRO, B.C.A., HOLANDA, J.N.F., "Efeito da temperatura de queima em algumas propriedades mecânicas de cerâmica vermelha". Cerâmica, v. 56, n. 339, pp. 237-243, 2010.

[41] VIEIRA, C.M.F., MONTEIRO, S.N., "Effect of the particle size of the grog on the properties of bricks", The Minerals, Metals \& Materials Society, n. 249-254, 2009.

[42] ASSOCIAÇÃO BRASILEIRA DE NORMAS TÉCNICAS. NBR 15310 - Componentes cerâmicosTelhas - terminologia, requisitos e métodos de ensaio. Rio de Janeiro, 2005.

[43] SANTOS, R.S., SOUZA, G.P., HOLANDA, J.N.F., "Caracterização de massas argilosas contendo resíduo proveniente do setor petrolífero e sua utilização em cerâmica estrutural", Cerâmica, v. 48, n. 307, p. 115120,2002

\section{ORCID}

Leonardo Alves Pinto

Thalia Delmondes de Souza

Daniel Bernardes Silva

Lizienny Pinheiro Peixoto

Maria Isabel Brasileiro Rodrigues https://orcid.org/0000-0002-0371-7424

https://orcid.org/0000-0002-2569-8906

https://orcid.org/0000-0002-3106-1557

https://orcid.org/0000-0002-0888-634X

https://orcid.org/0000-0001-7013-7078 